\title{
Tax Instruments Applied In Selected Developing Countries To Reduce Emissions From Electricity Generation - Recommendations For South Africa
}

\author{
Mareli Dippenaar, Stellenbosch University, South Africa
}

\begin{abstract}
The objective of the study was to compare the tax instruments (both incentives and disincentives) applied in selected developing countries (four BRICS countries, namely South Africa, China, Brazil and India) to reduce their emissions from electricity generation, in an attempt to identify areas for possible improvement or expansion in South Africa. Increased renewable energy, energy efficiency and research and development relating to these fields can contribute to the reduction of emissions resulting from electricity generation. A number of similar tax incentives were identified in the countries, the majority of which appear to be more beneficial in the comparative countries than in South Africa. It could be worth considering improving some of the existing incentives in South Africa to be more beneficial to taxpayers. In addition, a number of tax instruments that are applied in some of the comparative countries, were identified and suggested for consideration by the South African government.
\end{abstract}

Keywords: Tax Instruments; Tax Incentives; Tax Disincentives; Electricity; Emissions; South Africa; China; Brazil; India; Renewable Energy; Energy Efficiency

\section{INTRODUCTION}

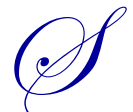

outh Africa, as in the rest of the world, is facing increasing growth in electricity demand, while growth in the supply of electricity is insufficient. In addition to this challenge of security of supply, the world faces the challenge of climate change that is caused, inter alia, by the emission of greenhouse gases (hereafter referred to as "emissions"). Urgent change is needed and government intervention is vital (Republic of South Africa, 2013a). Developing countries' energy challenges, which include reducing their energy-related emissions, could have serious consequences which, according to Ahuja and Tatsutani (2009), these countries would not be able to avoid, unless their governments intervene. Government policies need to be properly planned and appropriately implemented to address these challenges.

Coal is currently the largest contributor to South Africa's electricity supply, but has the most waste problems, including emissions (Republic of South Africa, 2004). The South African government is committed to helping reduce global emissions and aims to reduce their country's emissions by 34 per cent and by 42 per cent below business as usual emissions levels by 2020 and 2025, respectively (Republic of South Africa, 2009a). The South African government has admitted that fiscal and energy policies need to be aligned, since fiscal policies can either promote or hinder the accomplishment of energy policy objectives. It is also acknowledged that developments in other countries could be monitored, adapted and developed for local use (Republic of South Africa, 1998).

In an attempt to address the challenges of electricity shortages and increasing emissions from coalgenerated electricity, either the demand for, or supply of, electricity, or both, could be addressed. This would assist in the reduction of the demand for non-renewable electricity and/or the increase of the supply of renewable electricity that has fewer emissions. In line with its commitment to reduce emissions, the government of South Africa focuses 
on energy efficiency (EE) on the demand side and on increasing renewable energy (RE) on the supply side (Republic of South Africa, 2004 \& 2009b). Research and development (R\&D) also has the potential to improve EE and RE, if focused on these fields. EE refers to the ability to produce the same output, but with less energy consumed (Niesing, 2012). Tax instruments can contribute to the management of the demand for and consumption of electricity. This is evidenced by the successful use of EE tax incentives in the Netherlands (Lomas, 2012). Tax disincentives that target the demand for non-renewable electricity can also be applied (Bierbaum \& Friedman, 1992). Significant initial investment is required in order to generate electricity from renewable sources (Buffkins, 2012), which makes it challenging for these forms of electricity to compete with coal-generated electricity. Investment in RE could, however, be encouraged by the use of tax incentives, in combination with other instruments (CRS, 2005). In turn, this could improve electricity security and indirectly contribute to the reduction of the country's emissions. In addition, tax incentives could also stimulate investment in R\&D of technologies for electricity generation and use that can limit emissions, for example RE and EE technologies (KPMG, 2013b). The term "tax instruments" is used throughout the study as a collective noun for tax incentives, tax disincentives or both.

There is no one-size-fits-all government approach to effectively create a green economy and frequently a combination of policy instruments, which might include tax instruments, is necessary to reduce emissions (Republic of South Africa, 2006; Bierbaum \& Friedman, 1992; Nteo, 2012). According to Winkler (2005), studies have indicated that a combination of policy instruments is likely to be the most effective in achieving the largest environmental and economic benefits. Denmark is an example of a country that successfully applied a combination of complementary policies, including tax incentives, to encourage the development of its wind energy industry (Wiser, Hamrin \& Wingate, 2002). Nteo (2012) explains that an array of country-specific characteristics must be considered and governments should establish a combination of instruments that is appropriate for their circumstances. The combination of instruments applied in different countries is therefore likely to differ. However, governments searching for policy solutions to new or changing problems frequently consider policies in other countries (Dolowitz \& Marsh, 2000). Consequently, a comparison with other similar countries could assist the South African policymakers.

\section{RESEARCH OBJECTIVE, RESEARCH METHODOLOGY AND SCOPE}

The objective of this study is to identify areas for possible improvement or expansion of the tax instruments that are applied in South Africa to indirectly contribute to the reduction of emissions from the generation of electricity, by comparing it to the tax instruments applied for a similar purpose in certain other developing countries (China, Brazil and India). The rationale for comparing South Africa to these countries is set out in Dippenaar (2014).

A literature review of statutory law, accredited and non-accredited articles, books and dissertations was performed. This study would contribute to the existing academic literature regarding tax instruments, by being the first to highlight areas for improvement or expansion to the South African policymakers, based on the tax instruments applied in other developing countries that indirectly contribute to the reduction of emissions specifically associated with electricity generation.

In order to identify areas for consideration by the South African policymakers, only currently effective tax instruments are considered. The different tax instruments identified in each country is compared, regardless of the financial impact of the instruments, the effectiveness of the instruments in truly changing human behaviour, the remaining period of the instruments before they will be phased out or withdrawn, and the ease of compliance with the requirements for the respective incentives. As only literature written in English is considered, it is recognised that sources in other languages could contain tax proposals relevant to this study, but this could serve as a basis for expansion in future research by other researchers proficient in such other languages.

A brief background of electricity generation in each of the selected countries is supplied, followed by the relevant tax instruments which either directly or indirectly relate to electricity generation in these countries. The tax instruments applied in each country is then compared, in order to identify areas for possible improvement or expansion in South Africa. The study concludes by recommending considerations for improvement of the existing tax instruments as well as other areas of expansion in South Africa. 


\section{TAX INSTRUMENTS WITH POTENTIAL TO REDUCE EMISSIONS FROM ELECTRICITY GENERATION}

\section{South Africa}

The South African economy has experienced significant growth over a large number of years, resulting in a substantial increase in electricity demand. This is placing considerable strain on the country's electricity supply, which has not been growing sufficiently to provide for this increased demand for electricity. By far the majority of South Africa's electricity is generated from coal, an inexpensive and abundant resource. However, coal combustion is the main contributor to the country's high emissions, with negative environmental and health consequences as a result of the air pollution. The government of South African has committed to reducing its emissions by 2025 and is focussed on improving its EE. In addition, it plans to diversify the country's energy supply and is encouraging the use of RE technology (Republic of South Africa, 2004, 2009b \& 2012). The following tax instruments that can contribute to the reduction of emissions associated with electricity generation are currently applied in South Africa:

- $\quad$ Section 12B of the Income Tax Act no. 58 of 1962 (the Income Tax Act) grants accelerated depreciation allowances, in the ratio 50:30:20 and based on the cost of the assets, in respect of assets brought into use for the first time solely for the production of renewable electricity.

- In terms of section 12C of the Income Tax Act, accelerated depreciation allowances are granted in respect of new and unused R\&D machinery or plant brought into use for the first time. The allowance is granted in the ratio 50:30:20, based on the cost of the assets. The cost of a building used for R\&D is, however, only allowed in equal portions over a period of 20 years, in terms of section 13(1).

- $\quad$ Section 11D of the Income Tax Act grants a 150 per cent allowance in respect of expenditure incurred directly and solely on approved R\&D activities undertaken in South Africa. The expenditure must be incurred in the production of income, in carrying on any trade. The allowance is extended to pre-trade expenditure, in terms of section $11 \mathrm{~A}$, in respect of approved $\mathrm{R} \& \mathrm{D}$ activities.

- $\quad$ The proceeds from the disposal of certified emission reductions (CERs) from approved clean development mechanism (CDM) projects registered before 31 December 2020, which could include RE or EE projects, are exempt in terms of section $12 \mathrm{~K}$ of the Income Tax Act.

- A notional allowance is provided in terms of section $12 \mathrm{~L}$ of the Income Tax Act, based on energy savings achieved by EE projects. The allowance is calculated as 45 cents per kilowatt hour $(\mathrm{kWh})$, or equivalent, of energy savings during the year of assessment, made against a baseline measured at the beginning of the year. The taxpayer should carry on a trade and should make use of independent, registered and accredited professionals to measure and verify the value of the energy savings. The allowance is not allowed if a concurrent EE savings benefit is received from government or a semi-government agency.

- Section 12I of the Income Tax Act grants an allowance of 35 to 100 per cent in respect of the cost of new and unused manufacturing assets used in industrial policy projects (IPPs) that use improved EE and cleaner production technology, inter alia. This allowance is limited to major projects only.

- $\quad$ Certain assets and components related to the generation of wind energy are exempt from customs duties, in accordance with schedule no.1, part 1 of the Customs and Excise Act no. 91 of 1964 (Customs and Excise Act), when imported from certain countries.

- An environmental levy of 3.5 cents per $\mathrm{kWh}$ is levied on electricity generated from non-renewable sources, in terms of section 54A and schedule no.1, part 3B of the Customs and Excise Act.

- $\quad$ An environmental levy of 400 cents per light bulb is levied in terms of section 54A and schedule no.1, part $3 \mathrm{C}$ of the Customs and Excise Act, on incandescent light bulbs, to encourage EE and reduce the demand for electricity.

\section{China}

China was the leading global investor in RE in 2009, 2010, 2012 and 2013 (Bloomberg New Energy Finance, 2011 \& 2013; REN 21, 2014). The effective implementation of a combination of domestic policies, which include the use of tax incentives, and international support, has resulted in exceptionally high growth rates in the country's wind power industry since 2004 (Zhang, Chang, Huo \& Wang, 2009). The Chinese government is actively 
using tax instruments to promote a greener economy and is an example of a country that uses a combination of green tax incentives and disincentives (KPMG, 2013b). China has had a long history of using financial incentives and penalties to encourage desired outcomes (Seligsohn, Heilmayr, Tan \& Weischer, 2009). The following tax instruments that can contribute to the reduction of emissions associated with electricity generation are currently applied in China:

- $\quad$ Chinese residents that incur qualifying expenditures in respect of qualifying R\&D activities are entitled to a 150 per cent allowance in respect of such expenditure. R\&D activities could be in respect of RE or EE and qualifying expenditures include direct depreciation or amortisation of equipment or intangible assets (KPMG, 2012).

- $\quad$ A portion (two per cent) of the proceeds derived from the sale of CERs from CDM projects is deductible for enterprise tax ${ }^{1}$ purposes (KPMG, 2013a). This is because the Chinese government requires such a portion of the proceeds to be remitted to them (KPMG, 2009).

- Donations from international financial organisations, or certain other entities or individuals, and interest income from capital deposit or national bonds, received by a CDM, are exempt from enterprise income tax (KPMG, 2013a).

- $\quad$ A qualifying energy service company (ESCO) qualifies for an enterprise tax holiday from the year in which the revenue from the energy management contract $^{2}$ (EMC) project first arises. The tax holiday comprises full tax exemption during the first three years and thereafter another three years of paying tax at a reduced rate (KPMG, 2011).

- Any contribution received by an ESCO in respect of assets transferred to the energy user at the end of the term of the EMC, is exempt from enterprise tax (KPMG, 2011).

- $\quad$ An allowance is granted to an energy user in an EMC project in respect of reasonable expenditures actually incurred in accordance with the EMC project (KPMG, 2011).

- An enterprise tax credit of ten per cent of the investment amount is granted to enterprises that invest in special equipment for energy conservation and that use the equipment itself (KPMG, 2011 \& 2013a).

- Enterprises that derive income from qualifying environmental protection or energy conservation projects, are eligible for an enterprise tax holiday as follows: tax exemption during the first three years, followed by another three years of paying tax at a reduced rate on such income (KPMG, 2013a).

- $\quad$ An ESCO's revenue received in an EMC project is exempt from business tax ${ }^{3}$ (KPMG, 2013a).

- $\quad$ An ESCO's revenue derived from an EMC project is exempt from value-added tax (VAT) (KPMG, 2013a).

- $\quad$ The transfer of assets related to an EMC project from the ESCO to the energy user in the project, is exempt from VAT (KPMG, 2011).

- $\quad$ A customs duty exemption is granted in respect of the importation of certain wind and hydro power generation components (Chadbourne \& Park, 2010; Jungfeng, Pengfei \& Hu, 2010).

- A customs duty exemption is granted in respect of the importation of specified R\&D equipment by qualified foreign-invested R\&D centres (KPMG, 2012).

- Wind farm developers are eligible for a 50 per cent refund of VAT on the sale of self-manufactured wind electricity (KPMG, 2013a).

- $\quad$ Input VAT relating to equipment manufactured in China and purchased by qualified domestic R\&D institutes and foreign-invested R\&D centres, is refundable (KPMG, 2012).

- $\quad$ A VAT exemption is granted in respect of the importation of specified R\&D equipment by qualified foreign-invested R\&D centres (KPMG, 2012).

- An import duty exemption is granted in respect of the importation of equipment for own-use in certain domestic- and foreign-invested projects that are encouraged by the state, such as the development of energy savings technologies (KPMG, 2011).

\footnotetext{
${ }^{1}$ Enterprise tax is a tax imposed on the taxable income of corporations.

${ }^{2}$ An energy management contract is a mechanism whereby a contracted ESCO assists an energy user to reduce its energy consumption (KPMG, 2011).

${ }^{3}$ Business tax is a tax imposed on the turnover from the sale of immovable property and intangible goods, as well as on certain services that are not subject to VAT. VAT is imposed on the sale or importation of goods and the provision of processing, repair and replacement services within China. Consequently, business tax and VAT are mutually exclusive (Deloitte, 2013b).
} 
- $\quad$ High and new technology enterprises ${ }^{4}$ (HNTEs) pay enterprise tax at a reduced rate. Companies in the fields of RE, energy conservation, or R\&D could potentially qualify for the incentive (KPMG, 2012 \& 2013a).

- $\quad$ An HNTE in a special economic zone qualify for an enterprise tax holiday as follows: a two-year tax exemption and an additional three years of tax at a reduced rate (EY, 2013a).

\section{Brazil}

Unlike South Africa, where the majority of the country's total emissions is created by its energy sector (Republic of South Africa, 2013a), Brazil's agricultural industry is primarily responsible for its emissions. Brazil's energy sector is regarded as environmentally friendly when compared with the energy sectors of the majority of other major economies, even though it was the sector in the country that experienced the fastest growth in emissions during 2012 (Tollefson, 2013). Brazil is committed to developing its RE industry (Chacon, 2013) and has made significant investments in RE: it ranked ninth worldwide in terms of RE investment in 2012 (Bloomberg New Energy Finance, 2013). Almost half (46 per cent) of the primary energy in Brazil is produced from RE sources (Ministry of Mines and Energy, 2013), while RE sources only account for approximately 13 per cent of the global primary energy production (United Nations Environment Programme, 2012).

The United Nations Industrial Development Organization (UNIDO, 2009) identified Brazil as a country where government policies have assisted in establishing an RE market. Although tax incentives did assist in stimulating additional investment under Brazil's Incentive Programme for Alternative Sources of Energy, the programme is regarded as having successfully encouraged investors to commit resources to RE projects without relying on tax incentives (Chacon, 2013). The Brazilian government does apply some tax instruments to achieve green policy objectives, but is less active in using tax instruments for such a purpose than the majority of the other 20 countries listed in KPMG's green tax index (KPMG, 2013b). The following tax instruments that can contribute to the reduction of emissions associated with electricity generation are currently applied in Brazil:

- $\quad$ The full cost of acquisition of new machinery and equipment, including intangible assets, exclusively dedicated to R\&D, are allowed as a tax deduction in the year of acquisition (Deloitte, 2013a).

- Companies that incur qualifying expenditures directly and solely on $R \& D$ activities, benefit from a 160 to 200 per cent super allowance. The percentage depends on the number of researchers exclusively dedicated to the research and if the expenditure is incurred in respect of a registered patent (Deloitte, 2013a). The allowance is only available to Brazilian entities that choose to be taxed on actual income (EY, 2013b) and a valid tax clearance certificate is required (Deloitte, 2013a). In addition, specified accounting controls are required to record the R\&D expenditures (Deloitte, 2013a).

- $\quad$ Assets acquired and used in qualifying R\&D activities qualify for a 50 per cent reduction in federal $\mathrm{VAT}^{5}$ (Deloitte, 2013a; EY, 2013b).

- $\quad$ Equipment used to generate RE is generally exempt from federal VAT (KPMG, 2013a).

- $\quad$ Assets used to generate wind or solar energy qualify for an exemption from state VAT $^{6}$ (KPMG, 2013a).

- Certain assets and services acquired or imported by qualifying companies engaged in certain sectors, which include the generation of electricity, are exempt from federal social contributions ${ }^{7}$ for five years (Farah, 2013). RE generators could possibly qualify for these incentives.

- A reduced corporate income tax rate is available, for ten years, to companies whose activities fall into economic segments considered by the government to be a priority for the development of the Amazon or North-Eastern regions (PWC, 2013a). Both RE and EE projects could potentially qualify for this incentive (KPMG, 2013a).

\footnotetext{
${ }^{4}$ Also referred to as advanced and new technology enterprises.

${ }^{5}$ Industrialised product tax (referred to as IPI in Brazil) is an excise tax levied by the federal government on the manufacture and importation of goods into Brazil and is similar to a type of VAT. It is hereafter referred to as "federal VAT".

${ }^{6}$ ICMS is a VAT levied by state governments on the circulation and importation of goods and the provision of inter-state and inter-municipal transportation and communication services and is hereafter referred to as "state VAT".

${ }^{7}$ Federal social contributions are referred to as PIS and COFINS in Brazil and are levied on gross income. These contributions operate as noncumulative VAT-type taxes for certain taxpayers.
} 


\section{India}

India is the third largest greenhouse gas emitter globally (World Bank, 2013), mainly as a result of its energy sector's significant emissions (Upadhyaya, 2010). In 2007 the electricity generation sector was responsible for 37.8 per cent of the total emissions in India (Ministry of Environment and Forests, 2010). Coal-generated electricity accounts for 55 per cent and renewable electricity only for about 11 per cent of the total electricity generated in India (Bana, 2012). The government requires state electricity distributors to purchase a minimum percentage of electricity from renewable sources and therefore the electricity contribution from renewable sources is likely to increase in future (Upadhyaya, 2010).

According to the Ministry of New and Renewable Energy (MNRE, 2013), RE is a key element in India's National Action Plan on Climate Change. Significant investments have been made in RE and, according to Bloomberg New Energy Finance (2013), India ranked seventh globally in terms of investments in RE in 2012. A variety of government policy and support measures, including financial incentives (Chandrasekar \& Kandpal, 2004), fiscal policies such as tax incentives, preferential tariffs for renewable electricity and other promotional policies (Singh, 2007) have contributed to the growth in India's RE sector. The following tax instruments that can contribute to the reduction of emissions associated with electricity generation are currently applied in India:

- $\quad$ Accelerated depreciation allowances of 80 per cent are granted in respect of the cost of assets used to generate RE. For wind power projects, the incentive is, however, only available in respect of windmills installed on or before 31 March 2012 (KPMG, 2013a) or on or after 1 April 2014 (Government of India, 2014). Companies that installed windmills between 31 March 2012 and 1 April 2014 can only claim the standard allowance of 15 percent (KPMG, 2013a). In addition, companies that generate or distribute power are also allowed an additional allowance of 20 per cent, granted on the cost of new assets in the year of commissioning for manufacture (PWC, 2013b). The declining balance method is usually applied when calculating depreciation allowances, but power generation and/or distribution companies have the option to claim depreciation allowances using the straight line method at specified rates (PWC, 2013b). Companies can only claim the accelerated depreciation allowance if they do not benefit from the other generationbased incentives granted by the Indian government (KPMG, 2013a).

- $\quad$ Companies engaged in qualifying R\&D activities are entitled to a 100 or 200 per cent allowance in respect of qualifying expenditures incurred directly and solely on approved R\&D activities undertaken in India. The 200 per cent allowance is a weighted allowance and is only granted to certain manufacturers that undertake the research in an in-house research facility and who conclude an agreement with the government for cooperation in an R\&D centre and for the audit of the accounts maintained for that facility (EY, 2013b). The 100 per cent allowance is granted to entities that do not otherwise qualify for the 200 per cent super allowance and is also available in respect of certain pre-trade expenditures (KPMG, 2013b; EY, 2013b). Both the 200 per cent and 100 per cent allowances are in respect of both revenue and capital expenditures. However, the 200 per cent allowance is not granted in respect of land and buildings and the 100 per cent allowance is not granted in respect of land (EY, 2013b; KPMG, 2013b).

- $\quad$ Accelerated depreciation allowances of 80 per cent of the cost of certain energy saving devices, in the year of acquisition, are granted to companies that purchase such devices (KPMG, 2013b).

- $\quad$ A customs duty exemption or concession is granted in respect of specified RE goods (KPMG, 2013a; Sinha, 2011; Rewave Infra Solutions, 2013).

- A customs duty exemption or reduction is available to companies and certain research institutions that import specified R\&D assets (EY, 2013b).

- An excise duty exemption or concession is granted in respect of specified RE goods (KPMG, 2013a; Sinha, 2011; Rewave Infra Solutions, 2013).

- An excise duty exemption is granted to research institutions that acquire specified R\&D assets that were manufactured in India (EY, 2013b). 
- $\quad$ Units set up in special economic zones, which can include R\&D in respect of RE or EE, are eligible for various indirect tax benefits (Ministry of Commerce and Industry, 2009; PWC, 2012; KPMG, 2013c), including:

- $\quad$ customs and excise duties exemptions;

- $\quad$ central government sales $\operatorname{tax}^{8}$ abatements or exemptions;

- $\quad$ upfront exemptions from service tax ${ }^{9}$ and, in certain circumstances, even refunds; and

- $\quad$ exemptions from state $\mathrm{VAT}^{8}$ and other levies, as extended by the respective state governments.

- $\quad$ Significantly reduced VAT rates or VAT exemptions are offered by some state governments in respect of RE components (KPMG, 2013a; Rewave Infra Solutions, 2013).

- A ten-year tax holiday is available to companies engaged in the generation and/or distribution of power, which includes electricity generated from renewable sources, provided that the power generation began before 31 March 2014. However, such companies still have to pay a minimum alternative $\operatorname{tax}^{10}$ (MAT) (KPMG, 2013a; Bana, 2012).

- India applies a nationwide carbon tax on coal of 50 rupees per ton of coal produced in, or imported into, India (KPMG, 2013b). Although not directly targeting the generation of electricity, such a carbon tax could potentially serve as a disincentive for generators of electricity from coal, as it is likely to increase the input cost of coal.

- An allowance of 125 to 200 per cent of donations or contributions made to other specified entities for R\&D is granted to companies that make such donations or contributions (EY, 2013b).

- A 15-year phased tax holiday is granted to a company that sets its R\&D unit up in a special economic zone and that exports its R\&D services. The tax holiday applies to all profits earned from such R\&D services. Such units are, however, still liable for MAT (EY, 2013b).

\section{PROPOSED CONSIDERATIONS FOR IMPROVEMENT OF EXISTING INSTRUMENTS}

When comparing the tax instruments applied in South Africa with those applied in the comparative countries, the following types of similar incentives are identified:

- $\quad$ accelerated depreciation allowances in respect of RE assets;

- $\quad$ accelerated depreciation allowances in respect of R\&D assets;

- $\quad$ super allowances in respect of R\&D expenditures incurred;

- $\quad$ exempt proceeds from the disposal of CERs;

- $\quad$ incentives in respect of energy savings; and

- customs duty exemption in respect of assets used to generate wind energy.

The detail of these incentives is now investigated and compared to similar incentives in the comparative countries in order to identify areas for possible improvement in South Africa.

\section{Accelerated Depreciation Allowances: Renewable Energy Assets}

As is evident worldwide, economic instruments, such as green taxes (disincentives), fiscal incentives, market instruments and other direct regulatory measures, can be used to increase RE generation (Ashiabor, 2005). Both South Africa and India grant accelerated depreciation allowances to companies in respect of RE assets, as illustrated in Table 1. The growth in India's RE sector has been encouraged by a variety of policy and support measures taken by the government, including financial incentives (Chandrasekar \& Kandpal, 2004), fiscal policies such as tax incentives, preferential tariffs for renewable electricity and other promotional policies (Singh, 2007).

\footnotetext{
${ }^{8}$ Sales tax is levied on goods, either by the central government on interstate sales or by the state governments on intrastate sales (the latter is a type of VAT, referred to as "state VAT").

${ }^{9}$ Service tax is levied on certain services, such as specified banking and other financial services, insurance, scientific or technical consultancy, information technology services, telecommunication services and services performed by consulting engineers and management consultants.

${ }^{10}$ Should a company's income tax liability be less than 18.5 per cent of its book profit, as defined, including acess and applicable surcharges, a minimum alternative tax becomes payable (EY, 2013a).
} 
Table 1. Accelerated Depreciation Allowances: Renewable Energy

\begin{tabular}{|c|c|c|c|}
\hline Country & Incentive & Qualifying Assets & Requirements \\
\hline South Africa & $\begin{array}{l}\text { Depreciation over three years in } \\
\text { the ratio 50:30:20. }\end{array}$ & $\begin{array}{l}\text { Assets used in the generation of } \\
\text { renewable electricity. }\end{array}$ & $\begin{array}{l}\text { Brought into use for the first time } \\
\text { solely for the production of } \\
\text { renewable electricity. }\end{array}$ \\
\hline India & $\begin{array}{l}\text { Depreciation of } 80 \% \text { using the } \\
\text { declining balance method. Option } \\
\text { to use straight line method at } \\
\text { prescribed rates. } \\
\text { Additional } 20 \% \text { in first year (new } \\
\text { assets only). }\end{array}$ & $\begin{array}{l}\text { Assets used to generate RE. } \\
\text { Windmills installed after } 31 \\
\text { March } 2012 \text { or before } 1 \text { April } \\
2014 \text { only qualify for standard } \\
15 \% \text { allowance, not } 80 \% \text {. }\end{array}$ & $\begin{array}{l}\text { Can only claim this allowance if } \\
\text { company does not benefit from } \\
\text { the other generation-based } \\
\text { incentives. }\end{array}$ \\
\hline
\end{tabular}

The cumulative benefit after three years, in respect of second-hand assets, is approximately the same in both countries. However, the incentive in India appears to be more beneficial in the first year: 80 per cent of the cost may be claimed in year one, whereas, in South Africa, 80 per cent of the cost is only claimable in the first two years combined. In the case of new assets, the incentive in India is even more beneficial, as such assets qualify for an additional 20 per cent allowance in the year of commissioning for manufacture. The South African allowance extends to more types of assets, since windmills installed in India during the period from 31 March 2012 to 1 April 2014 do not qualify for the incentive, but in South Africa there is no such limitation. The South African government could possibly consider expanding the current allowances to be more beneficial in year one.

\section{Accelerated Depreciation: Research And Development Assets}

Sawyer (2005) analysed the impact of tax credits (incentives) on R\&D expenditure levels, by studying the results of other researchers' studies. He concluded that additional tax credits will normally produce additional R\&D expenditure and will generally be cost effective. The IPCC (2007 cited in Nortje, 2009) also found that tax incentives for the R\&D of RE, inter alia, are effective instruments to address climate change. All four of the selected countries apply tax incentives to promote $R \& D$. The detail of the accelerated depreciation allowances granted in respect of $R \& D$ assets in each of the countries is as follows:

Table 2. Accelerated Depreciation Allowances: Research And Development

\begin{tabular}{clll}
\hline Country & \multicolumn{1}{c}{ Incentive } & \multicolumn{1}{c}{ Qualifying Assets } & Requirements \\
\hline South Africa & $\begin{array}{l}\text { Depreciation over three years in } \\
\text { the ratio 50:30:20. }\end{array}$ & $\begin{array}{l}\text { Machinery or plant used in R\&D } \\
\text { activities. }\end{array}$ & $\begin{array}{l}\text { Assets must be new and unused } \\
\text { and brought into use for the first } \\
\text { time. }\end{array}$ \\
\hline \multirow{2}{*}{ China } & $\begin{array}{l}\text { 150\% allowance for R\&D } \\
\text { expenditure, including direct } \\
\text { depreciation or amortisation of } \\
\text { equipment or intangible assets. }\end{array}$ & $\begin{array}{l}\text { All R\&D assets, except those that } \\
\text { are not depreciated or amortised } \\
\text { (e.g. land) }\end{array}$ & $\begin{array}{l}\text { No such requirement was } \\
\text { identified. }\end{array}$ \\
\hline \multirow{3}{*}{ Brazil } & $\begin{array}{l}\text { Machinery, equipment and } \\
\text { intangible assets exclusively } \\
\text { dedicated to R\&D. }\end{array}$ & Assets must be new. \\
& $\begin{array}{l}\text { 200\% weighted allowance if } \\
\text { undertaken by a certain } \\
\text { manufacturer within an in-house } \\
\text { facility, otherwise only 100\% is } \\
\text { allowed. The incentives are in } \\
\text { respect of both revenue and } \\
\text { capital expenditures. }\end{array}$ & $\begin{array}{l}\text { 200\% weighted allowance: all } \\
\text { R\&D assets, except land and } \\
\text { buildings. } \\
100 \% \text { allowance: all R\&D assets, } \\
\text { except land. }\end{array}$ & $\begin{array}{l}\text { No such requirement was } \\
\text { identified. }\end{array}$ \\
& &
\end{tabular}

All four countries studied grant accelerated depreciation allowances to companies in respect of R\&D assets, as illustrated in Table 2. The incentives in all three comparative countries appear to be more beneficial than the incentive in South Africa. The South African government could possibly consider increasing the allowance to more than 100 per cent of the cost of certain $R \& D$ assets or expanding the current allowance to be more beneficial in year one, in order to encourage the R\&D of RE and EE technologies. 


\section{Super Allowances: Qualifying Research And Development Expenditure}

Many countries apply tax instruments to encourage $R \& D$, since innovation is critical to governments' green policy objectives (KPMG, 2013b). The following super allowances are available in each of the selected countries, each with its own requirements to be met in order to qualify for the allowance:

Table 3. Allowances For Research And Development Expenditures

\begin{tabular}{|c|c|c|c|}
\hline Country & Incentive & Qualifying Expenditure & Requirements \\
\hline South Africa & $\begin{array}{l}150 \% \text { allowance; includes pre- } \\
\text { trade expenditure. }\end{array}$ & $\begin{array}{l}\text { Expenditure incurred directly and } \\
\text { solely on R\&D activities. }\end{array}$ & $\begin{array}{l}\text { Approved R\&D activities } \\
\text { undertaken in South Africa. } \\
\text { In production of income, in } \\
\text { carrying on a trade. }\end{array}$ \\
\hline China & $\begin{array}{l}150 \% \text { allowance. } \\
\text { No specific mention of pre-trade } \\
\text { expenditure. }\end{array}$ & $\begin{array}{l}\text { Expenditure incurred directly and } \\
\text { solely on R\&D activities. }\end{array}$ & $\begin{array}{l}\mathrm{R} \& \mathrm{D} \text { undertaken by Chinese } \\
\text { residents. }\end{array}$ \\
\hline Brazil & $\begin{array}{l}160-200 \% \text { allowance, depending } \\
\text { on number of researchers } \\
\text { exclusively dedicated to research } \\
\text { and if expenditure is incurred in } \\
\text { respect of a registered patent. }\end{array}$ & $\begin{array}{l}\text { Expenditure incurred directly and } \\
\text { solely on R\&D activities. }\end{array}$ & $\begin{array}{l}\text { Undertaken by Brazilian entities } \\
\text { that choose to be taxed on actual } \\
\text { income. } \\
\text { Valid tax clearance certificate } \\
\text { required. Specific accounting } \\
\text { controls required to record R\&D } \\
\text { expenditure. }\end{array}$ \\
\hline India & $\begin{array}{l}200 \% \text { weighted allowance if } \\
\text { undertaken by a certain } \\
\text { manufacturer within an in-house } \\
\text { facility, otherwise only } 100 \% \text { is } \\
\text { allowed; the } 100 \% \text { allowance } \\
\text { extends to certain pre-trade } \\
\text { expenditures. }\end{array}$ & $\begin{array}{l}\text { Expenditure incurred directly and } \\
\text { solely on R\&D activities. }\end{array}$ & $\begin{array}{l}\text { Approved R\&D undertaken in } \\
\text { India. } 200 \% \text { allowance is only } \\
\text { granted if an agreement is } \\
\text { concluded with the government } \\
\text { for cooperation in an R\&D centre } \\
\text { and for the audit of the accounts } \\
\text { maintained for that facility. }\end{array}$ \\
\hline
\end{tabular}

All of the countries studied grant super allowances in respect of qualifying research and development expenditure incurred, as illustrated in Table 3. The incentives in Brazil and India appear to be more beneficial than the incentive in South Africa. The South African government could possibly consider increasing the allowance granted in certain circumstances in respect of $R \& D$ expenditure incurred, especially in order to encourage the $R \& D$ of RE and EE technologies. All the countries have their own strict requirements in order to be able to claim the super allowances for the incurral of approved R\&D expenditures.

\section{Exempt Proceeds From The Disposal Of Certified Emission Reductions}

The CDM was established as part of the Kyoto Protocol and provides a mechanism for Annex I (developed) countries to reduce their obligations to reduce their emissions by purchasing credits from CDM projects that avoid emissions in non-Annex (developing) countries. CDM projects can only be implemented in non-Annex countries and include RE, EE and other related projects that reduce emissions (Republic of South Africa, 2013b). China has the largest number of registered CDM projects in the world, while South Africa only ranks 14th globally in respect of the number of registered CDM projects (UNFCCC, 2014). An exemption in respect of the proceeds from the disposal of CERs, or a portion thereof, is granted in South Africa and China. Table 4 compares the detail of this incentive and shows that China has an additional incentive available to CDMs: 
Table 4. Clean Development Mechanism Incentives

\begin{tabular}{clll}
\hline Country & \multicolumn{1}{c}{ Incentive } & \multicolumn{1}{c}{ Qualifying Proceeds } & \multicolumn{1}{c}{ Requirements } \\
\hline South Africa & $\begin{array}{l}\text { The proceeds from the disposal } \\
\text { of CERs are exempt from income } \\
\text { tax. }\end{array}$ & $\begin{array}{l}\text { All proceeds from the disposal of } \\
\text { CERs derived from qualifying } \\
\text { CDM projects. }\end{array}$ & $\begin{array}{l}\text { CDM project should be registered } \\
\text { before 31 December 2020. }\end{array}$ \\
\hline \multirow{3}{*}{ China } & $\begin{array}{l}\text { A portion of the proceeds from } \\
\text { the disposal of CERs are } \\
\text { deductible for income tax } \\
\text { purposes. }\end{array}$ & $\begin{array}{l}\text { Only the portion of the proceeds } \\
\text { remitted to the government }(2 \%) \\
\text { is exempt. }\end{array}$ & $\begin{array}{l}\text { No such requirement was } \\
\text { identified. }\end{array}$ \\
\hline $\begin{array}{c}\text { China } \\
\text { (additional) }\end{array}$ & $\begin{array}{l}\text { Specified donations and interest } \\
\text { income received by a CDM are } \\
\text { exempt from income tax. }\end{array}$ & $\begin{array}{l}\text { Donations from international } \\
\text { financial organisations or other } \\
\text { entities/individuals; interest } \\
\text { income from capital deposit or } \\
\text { national bonds. }\end{array}$ & $\begin{array}{l}\text { No significant other requirements } \\
\text { were identified. }\end{array}$ \\
\hline
\end{tabular}

Both South Africa and China grant an exemption in respect of the proceeds from the disposal of CERs, or a portion thereof. The incentive in South Africa is more beneficial than the incentive in China, although China grants other incentives to CDM projects which South Africa does not.

\section{Incentives In Respect Of Energy Savings}

Ahuja and Tatsutani (2009) submits that EE is often the preferred approach in mitigating climate change, as EE improvements offer the largest and least costly emissions reduction potential in the short term and small, incremental and cumulative improvements in EE over long periods can deliver enormous benefits. South Africa and China both grant normal tax incentives to companies that generate energy savings, as illustrated in Table 5. There are also a number of requirements to be met in order to qualify for the respective incentives:

Table 5. Incentives In Respect Of Energy Savings Achieved

\begin{tabular}{|c|c|c|c|}
\hline Country & Incentive & Qualifying Projects & Requirements \\
\hline South Africa & $\begin{array}{l}\text { A notional allowance based on energy } \\
\text { savings achieved by EE projects. }\end{array}$ & EE projects. & $\begin{array}{l}\text { Need to carry on a trade. } \\
\text { Independent, registered and accredited } \\
\text { professionals are required to measure and } \\
\text { verify the energy savings. } \\
\text { The allowance is only claimable in the first } \\
\text { year of the project, unless continuous savings } \\
\text { are realised. } \\
\text { The allowance is not allowed if a concurrent } \\
\text { EE savings benefit is received from } \\
\text { government or a semi-government agency. }\end{array}$ \\
\hline China & $\begin{array}{l}\text { A three-year tax exemption and a reduced } \\
\text { rate of income tax for a further three } \\
\text { years, available to qualifying ESCOs; if } \\
\text { the energy user pays for the transfer of } \\
\text { assets at the end of the project term from } \\
\text { the ESCO, the revenue is exempt in the } \\
\text { hands of the ESCO; the energy user can } \\
\text { claim an allowance for reasonable } \\
\text { expenditures incurred on the project. }\end{array}$ & EMC projects. & $\begin{array}{l}\text { A combination of qualitative and } \\
\text { quantitative criteria is imposed on both the } \\
\text { EMC project and the ESCO. }\end{array}$ \\
\hline $\begin{array}{l}\text { China } \\
\text { (additional) }\end{array}$ & $\begin{array}{l}\text { A company that derives income from a } \\
\text { qualifying environmental protection or } \\
\text { energy conservation project is entitled to } \\
\text { a three-year tax exemption and a further } \\
\text { three years of paying tax at a reduced rate } \\
\text { on such income. }\end{array}$ & $\begin{array}{l}\text { Environmental } \\
\text { protection or energy } \\
\text { conservation projects. }\end{array}$ & $\begin{array}{l}\text { No significant other requirements were } \\
\text { identified. }\end{array}$ \\
\hline
\end{tabular}

\footnotetext{
${ }^{11}$ Since a new baseline is calculated each year, based on the electricity usage of the preceding year, section 12L actually encourages continuous energy savings (Kasavel, 2014).
} 
The incentives in China appear to be more beneficial than the incentive granted in South Africa and the South African government could possibly consider expanding the current incentive. Various requirements need to be met in order to benefit from the notional allowance in South Africa, as well as from all the incentives available to the parties to qualifying EMC projects in China. The requirements that need to be met in order to qualify for the South African incentive appear to be more strenuous to comply with, which might discourage taxpayers from applying. Thetard (2013) also points out that the expected benefit of claiming the South African tax allowance should exceed the expenditure incurred in the measurement and verification process, before a taxpayer would be likely to utilise this incentive. The South African government could possibly consider simplifying the requirements of the allowance.

\section{Customs Duty Exemption: Renewable Energy}

The use of fiscal incentives is one type of government approach that is proven to be effective in promoting a RE industry (KPMG, 2013a). South Africa, China and India all grant customs duty exemptions in respect of the importation of certain RE generation assets, as illustrated in Table 6:

Table 6. Customs Duty Exemption: Renewable Energy

\begin{tabular}{clll}
\hline Country & \multicolumn{1}{c}{ Incentive } & \multicolumn{1}{c}{ Qualifying Assets } & \multicolumn{1}{c}{ Requirements } \\
\hline South Africa & Customs duty exemption. & $\begin{array}{l}\text { Certain assets and components } \\
\text { related to generation of wind } \\
\text { energy. }\end{array}$ & $\begin{array}{l}\text { Only granted when items } \\
\text { originate in certain countries. }\end{array}$ \\
\hline \multirow{2}{*}{ China } & Customs duty exemption. & $\begin{array}{l}\text { Certain wind and hydro power } \\
\text { generation components. }\end{array}$ & $\begin{array}{l}\text { No significant other requirements } \\
\text { were identified. }\end{array}$ \\
\hline \multirow{2}{*}{ India } & $\begin{array}{l}\text { Customs duty exemption or } \\
\text { concession. }\end{array}$ & $\begin{array}{l}\text { Specified goods, such as RE } \\
\text { spares and equipment required } \\
\text { for setting up an RE power } \\
\text { project. }\end{array}$ & $\begin{array}{l}\text { No significant other requirements } \\
\text { were identified. }\end{array}$ \\
\hline
\end{tabular}

It is clear that the incentives in China and India are granted in respect of more types of RE assets than the incentive in South Africa, which is only available for certain wind generation assets and components. The South African government could possibly consider extending the incentive to more types of RE assets.

The next section compares the tax instruments applied in the selected countries in order to identify tax instruments that are applied in some of the other countries, but not in South Africa, in order to identify possible tax instruments that warrant consideration by the South African policymakers.

\section{PROPOSED CONSIDERATIONS FOR EXPANSION OF EXISTING TAX INSTRUMENTS}

The following types of tax instruments are applied in more than one of the countries studied, but not in South Africa and could consequently be considered for use in South Africa:

- $\quad$ indirect tax incentives for R\&D assets;

- $\quad$ indirect tax incentives for assets used to generate RE; and

- $\quad$ normal (direct) tax incentives for investment in EE assets.

Indirect tax incentives for R\&D assets are currently implemented in China (KPMG, 2012), Brazil (Deloitte, 2013a; EY, 2013b) and India (EY, 2013b). The incentives applied in these countries include VAT, customs and excise duty exemptions on importation of certain R\&D assets into China and India; input VAT refunds on acquisition of R\&D manufactured in China; and a reduced rate for federal VAT in Brazil on R\&D assets.

Indirect tax incentives for assets used to generate RE are currently also implemented in China (KPMG, 2013a; Chadbourne \& Park, 2010; Jungfeng, Pengfei \& Hu, 2010), Brazil (KPMG, 2013a) and India (KPMG, 2013a; Sinha, 2011; Rewave Infra Solutions, 2013). The incentives applied include customs and excise duty exemptions or concessions in China and India; federal and state VAT exemptions in Brazil; and a VAT reduction or 
exemption in some states in India. The only indirect tax incentives available in South Africa are customs duty exemptions of certain assets used to generate wind energy.

Both China and India currently apply normal tax incentives to encourage investment in EE assets. In China a tax credit is granted for investment in EE assets (KPMG, 2011 \& 2013a) and in India accelerated depreciation allowances are granted in respect of such assets (KPMG, 2013b). In South Africa EE assets are likely to qualify for a standard depreciation allowance in terms of section 11(e) or 12C of the Income Tax Act. Section 11(e) is available in respect of assets used for purposes of a taxpayer's trade and section $12 \mathrm{C}$ is available in respect of machinery or plant used for purposes of a taxpayer's trade, directly in a process of manufacture. Furthermore, certain EE assets could qualify for the additional allowance granted by section 12I in respect of the cost of new and unused manufacturing assets, limited to certain thresholds, used in qualifying IPPs. One of the many requirements for a project to be approved as an IPP is the use of improved EE and cleaner production technology. There are, however, strict criteria to qualify for this additional allowance and only very large projects can potentially qualify. It is therefore likely that most EE assets will only qualify for the standard allowance in terms of either section 11(e) or 12C. It is worth considering preferential treatment for companies acquiring EE assets in South Africa.

Other types of incentives that warrant consideration by the South African government, are income tax exemptions (tax holidays) and reduced rates of income taxes in respect of qualifying RE, EE or R\&D projects. Such incentives are utilised by the Chinese, Brazilian and Indian governments, albeit not in respect of the same types of transactions. The following tax exemptions and reduced tax rates identified in the study are applied in these three countries:

- $\quad$ HNTEs in China pay tax at a reduced rate.

- An HNTE in a special economic zone in China is entitled to a two-year tax holiday, followed by another three years of paying income tax at a reduced rate.

- $\quad$ An ESCO in China is granted a three-year tax exemption, followed by another three years of paying income tax at a reduced rate.

- $\quad$ An entity in China that receives income from a qualified environmental protection or energy conservation project is entitled to a three-year exemption from income tax, where after income tax is paid at a reduced rate for another three years.

- $\quad$ Approved companies whose activities fall into economic segments considered by the Brazilian government to be a priority for the development of the Amazon or North-Eastern regions pay income taxes at a reduced rate for ten years.

- Indian companies engaged in the generation and/or distribution of power, are entitled to a ten-year tax holiday, provided that the power generation began before 31 March 2014.

- A 15-year phased tax holiday is granted to a unit in a special economic zone in India that exports R\&D services.

Additional incentives worth considering, although they are only available in China and India, respectively, are the income tax exemption of certain donations and interest income received by a CDM; and the 125 to 200 per cent weighted allowance available to companies that make donations or contributions to approved entities for scientific research. In South Africa, only the proceeds from the disposal of CERs derived from qualifying CDM projects are exempt from income tax and the South African government could possibly consider additional incentives, such as the exemption of certain income received by a CDM. Section 18A of the South African Income Tax Act provides only a limited allowance in respect of bona fide donations to certain beneficiaries, including nonprofit entities and institutes or bodies established by law that, in the furtherance of their sole or principal object, conduct scientific, technical or industrial research, inter alia. However, these beneficiaries should carry on certain public benefit activities and it is unlikely that an entity conducting R\&D activities would fall into any of these approved categories of activities. A similar incentive in respect of donations or contributions made to certain entities for scientific research in South Africa warrants consideration by the South African government. 


\section{CONCLUSION}

Various types of tax incentives that are applied in South Africa and some of the other countries were identified. Certain tax instruments applied in South Africa are similar to instruments applied in China, Brazil and/or India, although the latter instruments appear to be more beneficial than the instruments applied in South Africa in respect of accelerated depreciation in respect of RE assets; accelerated depreciation in respect of R\&D assets; super allowances for R\&D; incentives in respect of energy savings; and customs duty exemptions in respect of RE assets. The South African government could possibly consider expanding the current incentives in order to encourage RE, EE or R\&D relating to these fields. This could assist in keeping the emissions from electricity generation from increasing.

A number of tax instruments that are applied in some of the other countries were identified and suggested for consideration by the South African government. There is, however, no standard recipe or blueprint that indicates which instruments to apply in which circumstances and each government should consider its own specific circumstances when designing and implementing government policies and measures. It is recommended that the South African government use sound judgement and evaluate the advantages and disadvantages of the various incentives proposed for consideration in the context of the South African circumstances, characteristics, challenges, objectives and available resources.

\section{AUTHOR INFORMATION}

Mareli Dippenaar: Chartered Accountant (SA); MAcc Taxation (Stellenbosch); postgraduate financial accounting lecturer in the School of Accountancy at the University of Stellenbosch. E-mail: lagrange@ sun.ac.za

\section{REFERENCES}

Ahuja, D. \& Tatsutani, M. (2009). Sustainable energy for developing countries. S.A.P.I.E.N.S., 2(1).

Ashiabor, H. (2005). Fostering the Development of Renewable Energy through Green Taxes and Other Instruments. Bulletin for International Taxation, 59(7), 295-305.

Bana, S. (2012, May/June). India powers ahead. Renewable Energy Focus, 20-24.

Bierbaum, R. \& Friedman, R.M. (1992). The Road to Reduced Carbon Emissions. Issues in Science and Technology, 8(2), 58-65.

Bloomberg New Energy Finance. (2011, January 12). Solar surge drives record clean energy investment in 2011. Bloomberg New Energy Finance.

Bloomberg New Energy Finance. (2013). Global Trends in Renewable Energy Investment 2013. Frankfurt: Frankfurt School of Finance \& Management.

Buffkins, S. (2012, January 20). What will the future electricity generating landscape be like? Part 1. Psiclone News. [Online]. Retrieved September 6, 2013:

http://www.psiclone.co.za/index.php?option=com_k2\&view=item\&id=81: what-will-the-future-electricitygenerating-landscape-be-like? \&Itemid=235.

Chacon, L.B. (2013). Long-term contracting the way to renewable energy investment: lessons from Brazil applied to the United States. Emory Law Journal, 62(6), 1563-1612.

Chadbourne \& Parke LLP. (2010). China Renewables Update: new regulatory and policy initiatives focused on wind, solar photovoltaic and biomass industries. [Online]. Retrieved May 14, 2014: http://www.chadbourne.com/China_Renewables_Update_Sept2010_projectfinance/.

Chandrasekar, B. \& Kandpal, T.C. (2004). Effect of financial and fiscal incentives on the effective capital cost of solar energy technologies to the user. Solar Energy, 78(2), 147-156.

CRS (Centre for Resource Solutions). (2005). International Tax Incentives for Renewable Energy: Lessons for Public Policy (draft report). San Francisco.

Deloitte. (2013a). 2013 Global Survey of R\&D Tax Incentives. [S.1.].

Deloitte. (2013b). Taxation and Investment in China 2013. [S.1.].

Dippenaar, M. (2014). The role of tax instruments in reducing emissions from electricity generation in selected developing countries - a comparative study. Unpublished master's thesis, University of Stellenbosch.

Dolowitz, D.P. \& Marsh, D. (2000). Learning from Abroad: The Role of Policy Transfer in Contemporary Policy- 
Making. Governance: An International Journal of Policy Administration, 13(1), 5-24.

EY. (2013a). Worldwide corporate tax guide 2013-14. [S.1.].

EY. (2013b). Worldwide R\&D incentives reference guide 2013-2014. [S.1.].

Farah, A.G.V. (2013, July 1). Tax Reduction for Infrastructure Development in Brazil. The Brazil Business.

Government of India. Income Tax Department. (2014). New Appendix I: Table of rates at which depreciation is admissible. [Online]. Retrieved October 14, 2014: http://www.incometaxindia.gov.in/Pages/rules/incometax-rules-1962.aspx.

Junfeng, S., Pengfei, G. \& Hu, G. (2010). China Wind Power Outlook. [S.1.]: Global Wind Energy Council.

Kasavel, K. (2014). Energy efficiency tax incentive section 12L of the Income Tax Act comes into effect. [Online]. Retrieved May 7, 2014: http://urbanearth.co.za/articles/energy-efficiency-tax-incentive-section-121-incometax-act-comes-effect.

KPMG. (2009). Corporate Income Tax Incentives for Clean Development Mechanism Projects. China alert: Tax and regulatory developments, Issue 34.

KPMG. (2011). Tax milestone in energy saving industry - Second batch of energy service companies released. China alert: Energy \& Natural Resources Focus, Issue 2.

KPMG. (2012). Securing R\&D Tax Incentives in China. Hong Kong.

KPMG. (2013a). Taxes and incentives for renewable energy. [S.1.].

KPMG. (2013b). The KPMG Green Tax Index 2013. [S.1.].

KPMG. (2013c, July 8). Revamp of Special Economic Zones Exemption under Service tax. KPMG Flash News.

Lomas, U. (2012, July 23). Dutch Investment Tax Boosts Renewable Energy. Tax News. [Online]. Retrieved April 17, 2014: http://www.taxnews.com/news/Dutch_Investment_Tax_Boosts_Renewable_Energy_56469.html.

Ministry of Commerce and Industry. (2009). Special Economic Zones in India. [Online]. Retrieved July 12, 2014: http://sezindia.nic.in.

Ministry of Environment and Forests. (2010). India: Greenhouse Gas Emissions 2007. New Delhi.

Ministry of Mines and Energy. (2013). Brazilian Energy Balance Year 2012. Rio de Janeiro.

MNRE (Ministry of New and Renewable Energy). (2013). Annual Report: 2012-13. New Delhi.

Niesing, G. (2012). Assessing the barriers companies face towards the implementation of corporate energy efficiency strategies. Unpublished master's thesis, North-West University.

Nortje, D. (2009). A literature study of renewable energy tax incentives. Unpublished master's thesis, University of Pretoria.

Nteo, L.D. (2012). Role of market based instruments in transitioning to a low carbon economy: experiences from BRICS countries and lessons for South Africa. Unpublished master's thesis, Gordon Institute of Business Science University of Pretoria.

PWC. (2012, April). Research and development in the BRICS. Global R\&D Tax News.

PWC. (2013a). Doing Business and Investing in Brazil. [S.1.].

PWC. (2013b). Worldwide Tax Summaries: Corporate Taxes 2013/14. [S.1.].

REN 21. 2014. Renewables 2014 Global Status Report. Paris.

Republic of South Africa. (1962). Income Tax Act 58 of 1962. [Laws.] Pretoria: Government Printer.

Republic of South Africa. (1964). Customs and Excise Act 91 of 1964. [Laws.] Pretoria: Government Printer.

Republic of South Africa. Department of Minerals and Energy. (1998). White Paper on the Energy Policy of the Republic of South Africa. Government Gazette no. 19606, 17 December.

Republic of South Africa. Department of Minerals and Energy. (2004). White Paper on Renewable Energy November 2003. Government Gazette no. 26169, 14 May.

Republic of South Africa. National Treasury. (2006). Draft Policy Paper: A framework for considering marketbased instruments to support environmental fiscal reform in South Africa. Pretoria: Government Printer.

Republic of South Africa. The Presidency. (2009a, December 18). Address by President Jacob Zuma at UN Climate Change Conference; Copenhagen. [Online]. Retrieved September 5, 2013: http://www.thepresidency.gov.za/pebble.asp?relid=555.

Republic of South Africa. Department of Minerals and Energy. (2009b). National Energy Efficiency Strategy for South Africa, March 2005, Reviewed October 2008. Government Gazette no. 32249, 22 May.

Republic of South Africa. (2012). South Africa Yearbook 2011/12. Pretoria: Government Printer.

Republic of South Africa. National Treasury. (2013a). Policy paper for public comment: Carbon tax policy paper: Reducing greenhouse gas emissions and facilitating the transition to a green economy. Pretoria: 
Government Printer.

Republic of South Africa. National Treasury. (2013b). Explanatory Memorandum on the Taxation Laws Amendment Bill 2013. Pretoria: Government Printer.

Rewave Infra Solutions. (2013). Wind Power in India: Industry Information Insights 2013. [S.1.:s.n.].

Sawyer, A. (2005). Reflections on providing tax incentives for research and development: New Zealand at the cross roads. Journal of Australian Taxation, 8(1), 111-149.

Seligsohn, D., Heilmayr, R., Tan, X. \& Weischer, L. (2009). China, The United States, and the Climate Change Challenge. World Resource Institute, WRI Policy Briefs, October.

Singh, A. (2007). A market for renewable energy credits in the Indian power sector. Renewable and Sustainable Energy Reviews, 13(3), 643-652.

Sinha, A. (2011, February/March). Renewable Energy in India: Scope for Foreign Investment. Alternative Energy eMagazine. [Online]. Retrieved July 6, 2014: www.altenergymag.com/emagazine/2010/12/renewableenergy-in-india-scope-for-foreign-investment/1654.

Thetard, S. (2013). Finally a tax rebate with the energy to change. [Online]. Retrieved May 6, 2014: http://energyefficiencycourses.co.za/category/blog/.

Tollefson, J. (2013, June 5). Brazil reports sharp drop in greenhouse emissions. Nature: international weekly journal of science. [Online]. Retrieved January 28, 2014: http://www.nature.com/news/brazil-reports-sharp-dropin-greenhouse-emissions-1.13121.

UNFCCC (United Nations Framework Convention on Climate Change). (2014). Distribution of registered projects by Host Party. [Online]. Retrieved October 14, 2014:

http://cdm.unfccc.int/Statistics/Public/CDMinsights/index.html.

UNIDO (United Nations Industrial Development Organisation). (2009). Scaling up Renewable Energy in Africa: $12^{\text {th }}$ Ordinary Session of Heads of State and Governments of the African Union. Austria.

United Nations Environment Programme. (2012). Year book: emerging issues in our global environment. Nairobi. Upadhyaya, P. (2010). Is emission trading a possible policy option for India? Climate Policy, 10(5), $560-574$.

Winkler, H. (2005). Renewable energy policy in South Africa: policy options for renewable electricity. Energy Policy, 33(1), 27-38.

Wiser, R., Hamrin, J. \& Wingate, M. (2002). Renewable energy policy options for China: a comparison of renewable portfolio standards, feed-in tariffs, and tendering policies. [S.1.]: Center for Resources Solutions.

World Bank. (2013). World Development Indicators 2013. Washington, DC: World Bank.

Zhang, X., Chang, S., Huo, M. \& Wang, R. (2009). China's wind industry: policy lessons for domestic government interventions and international support. Climate Policy, 9(5), 553-564. 


\section{NOTES}

